Tropical Journal of Pharmaceutical Research February 2011; 10 (1): 33-40

(C) Pharmacotherapy Group Faculty of Pharmacy, University of Benin

Benin City, 300001 Nigeria.

All rights reserved.

Research Article

Available online at http://www.tjpr.org

\title{
In Vitro Safety Assessment of the Effect of Five Medicinal Plants on Human Peripheral Lymphocytes
}

\section{KN Varalakshmi*, CG Sangeetha, US Samee, G Irum, H Lakshmi and SP Prachi}

Department of Biotechnology, Centre for Post-Graduate Studies, Jain University, 18/3, $9^{\text {th }}$ Main, III Block, Jayanagar, Bangalore - 560 011, India

\begin{abstract}
Purpose: To evaluate, using ethnomedical data approach, five Indian plants used in traditional medicine for cancer and other diseases for their safety and cytotoxic activity on human lymphocytes.

Methods: The antiproliferative effect of the 50, 100 and $200 \mu \mathrm{g} / \mathrm{ml}$ aqueous extracts of five plants (leaves of Phyllanthus niruri, Coleus aromaticus, Azadirachta indica and Camellia sinensis, and dried fruit rind of Garcinia indica) were evaluated in vitro using trypan blue dye exclusion and clonogenic assay methods on two cell lines - Balb/c 3T3 mouse fibroblasts and human peripheral lymphocytes.

Results: Among the five plants used traditionally to treat cancer and other infections, two of them (A. indica and C. aromaticus) exhibited cytotoxic effects on lymphocytes. Two other plants (G. indica and $P$. niruri) exhibited pronounced cytotoxic effects. Another plant (Camellia sinensis) exhibited cytostimulatory effect (>50\% cell proliferation). For the plants that are traditionally used in anticancer therapy, there was a correlation between the reported use of these plants and their cytotoxic activity on lymphocytes.

Conclusion: The plant extracts of the leaves of $P$. niruri, $C$, aromaticus and $A$. indica, and the dried fruit rind of $G$. indica are cytotoxic to lymphocytes and this lends some credence to their traditional use for cancer treatment. However, green tea (C. sinensis) is cytostimulatory and safe for consumption.
\end{abstract}

Keywords: Balb/c mouse fibroblasts, Cytostimulatory, Cytotoxic, Lymphocytes, Traditional medicine.

*Corresponding author: E-mail: varalakshmikn@yahoo.co.in, varalakshmikn.cpgs@jaingroup.info; Tel: +91-8043226500; Fax: +91-80-43226500 


\section{INTRODUCTION}

The medicinal use of plants is probably as old as mankind itself. Plants have continued to be a valuable source of natural products for maintaining human health, as studies on natural therapies have intensified. More than 150,000 plant species have been studied, and several of them contain therapeutic substances [1,2]. The use of plant compounds for pharmaceutical purposes has gradually increased. According to the World Health Organization [3], medicinal plants are probably the best source of a variety of drugs. About $80 \%$ of individuals in developed countries use traditional medicine containing compounds derived from medicinal plants [4].

The use of plant extracts and phytochemicals can be of great significance in therapeutic treatments [5]. However, medicinal plants, and indeed plants in general, synthesize toxic substances which in nature act as a defense against infections, insects and herbivores but which often affect the organisms that feed on them. Thus, an assessment of their cytotoxic potential is necessary to ensure relatively safe use of medicinal plants [6].

The species Azadirachta indica (neem), Phyllanthus niruri, Garcinia indica and Coleus aromaticus (doddapatre) are examples of plants commonly used in popular medicine. Neem has been successfully used for centuries to reduce tumors by herbalists throughout Southeast Asia. [7]. Phyllanthus niruri has been found to exhibit marked inhibitory effect on hepatitis B virus which is evident by its wide application in cases of chronic jaundice. Phyllanthus niruri Linn has been used in Ayurvedic medicine for over 2,000 years in the therapy of a wide range of ailments such as jaundice, gonorrheoa, 'frequent menstruation' and diabetes, as well as topically as a poultice for skin ulcers, sores, swelling, and itchiness [8]. The plant is said to play a role in liver disorders due to its febrifuge, antiseptic, astringent, stomachic, deobstruent and diuretic actions [9] and has also been used to correct GIT problems such as dyspepsia, colic, diarrheoa and dysentery, and to tone the GIT tract back to functionality [10]. The young shoots of the plant are administered in the form of an infusion for the treatment of chronic dysentery [11]. Garcinol, a polyisoprenylated benzophenone from the Garcinia indica (kokum) fruit rind, has been claimed to be an anti-inflammatory and anticancer agent [12]. Rao et al [13] reported the antioxidant, anticlastogenic and radioprotective effect of Coleus aromaticus on Chinese hamster fibroblast cells (V79).

The use of plant compounds for pharmaceutical purposes has gradually increased. Such plants should be investigated to better understand their properties, safety and efficiency. The objective of this study was to investigate five plants for acute cytotoxicity in vitro on lymphocytes from human peripheral blood.

\section{EXPERIMENTAL}

\section{Plant materials}

The plants evaluated were Azhadiracta indica (neem), Garcinia indica (kokum), Phyllanthus niruri, Camellia sinensis (green tea) and Coleus aromaticus (doddapatre). Fresh plant materials were collected from Lalbagh, Bangalore, India during the month of March 2009, and identified by Professor SB Sullia. A voucher specimen (no. JUH 125) was deposited at the herbarium of Jain University Research Center, Bangalore, India.

The leaves of the plants and the fruit rind of Garcinia indica were shade-dried and coarsely powdered with a grinder.

\section{Cell lines}

Balb/c Mouse 3T3 fibrobalst was procured from National Center for Cell Sciences (NCCS), Pune, India while human peripheral lymphocytes were isolated from peripheral blood in our laboratory. 


\section{Isolation of lymphocytes}

Lymphocytes were obtained from the blood of five healthy, male and female individuals, about 20 years of age, apparently free from infection and who had not received any medical treatment in the preceding six months. The ethical guidelines for research of the Indian Council of Medical Research (ICMR) [14] were followed with regard to blood sampling. The cells were incubated at $37{ }^{0} \mathrm{C}$ for $8 \mathrm{~h}$ in $5 \mathrm{~mL}$ of culture medium consisting of $90 \%$ Dulbecco's Modified Essential Medium (DMEM) and $10 \%$ foetal bovine serum [15]. Samples were taken from the cultures for determining cell count by haemocytometry. HiSep medium (an isoosmotic, low viscosity medium containing polysucrose and sodium diatrizoate adjusted to a density of $1.0770 \pm 0.0010 \mathrm{~g} / \mathrm{ml}$ ) was used for the isolation. .

\section{Subculturing lymphocytes for treatment}

$1 \mathrm{~mL}$ of HiSep media was layered with $3 \mathrm{~mL}$ of diluted blood and centrifuged at $800 \mathrm{rpm}$ for $30 \mathrm{~min}$. The lymphocytes, which appeared as a buffy coat layer at the interface of HiSep Media and plasma, were aspirated and again centrifuged with phosphate buffered saline for purification. The lymphocytes were resuspended in $2 \mathrm{ml}$ of DMEM cell culture medium. From this, $0.5 \mathrm{ml}$ was transferred to four new cell culture flasks containing $4 \mathrm{ml}$ of fresh DMEM media. Streptomycin $(1 \%)$ and penicillin (1\%) were added to inhibit the bacterial contamination. These flasks were kept in a $\mathrm{CO}_{2}$ incubator at $37^{\circ} \mathrm{C}$.

\section{Preparation of plant materials}

The leaves (fruit rind in the case of Garcinia indica) (5 g) of each plant were homogenized in $100 \mathrm{ml}$ of distilled water in a $250 \mathrm{ml}$ sterile conical flask. The extracts were filtered through Whatmann filter paper no. 1 and stored at $4^{\circ} \mathrm{C}$ for further use. Just prior to the tests, the extracts were filter-sterilized with a $0.22 \mu \mathrm{m}$ membrane filter and then diluted to
50, 100 and $200 \mu \mathrm{g} / \mathrm{ml}$ in fresh dimethyl sulphoxide (DMSO).

\section{Treatment of lymphocytes with plant extracts}

The flasks containing lymphocytes were inoculated with either 50,100 or $200 \mu \mathrm{g} / \mathrm{ml}$ of the plant extracts. One flask was kept as control. All the treatments were performed in triplicate and the mean ( \pm standard error) was calculated in each case. The flasks were labelled appropriately and kept in a $\mathrm{CO}_{2}$ incubator at $37{ }^{\circ} \mathrm{C}$ for one week and monitored regularly during the period. Thereafter, the cells were counted with a haemocytometer and cell viability determined by trypan blue dye exclusion method. In this procedure, an aliquot of the cell suspension

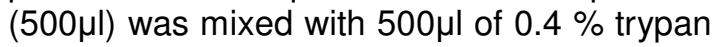
blue (in phosphate buffered saline). This

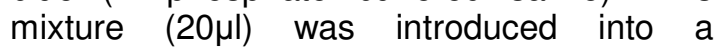
haemocytometer and observed under a light microscope. Viable cells were transparent and dead cells were blue.

\section{Antiproliferation test on Balb/c 3T3 mouse fibroblasts}

The fibroblasts were grown in $25 \mathrm{~cm}^{2}$ flasks containing DMEM with $10 \%$ foetal bovine serum and streptomycin (1\%) and penicillin $(1 \%)$ in a $5 \% \mathrm{CO}_{2}$ incubator at $37^{\circ} \mathrm{C}$. The cells were harvested from the flasks after brief trypsinization which was carried out as follows[2]. The culture medium was removed and the cells were washed in a balanced salt solution. Thereafter, $2 \mathrm{ml}$ of trypsin-EDTA solution was added to the cells and the vessel placed in the incubator for $2 \mathrm{~min}$. The cells were observed under a light microscope.

Clonogenic assays using logarithmically growing cells were performed according to the published methods [16-17]. Briefly, approximately 400 cells obtained from subconfluent culture flasks were seeded per tissue culture dish in $5 \mathrm{ml}$ of medium (five dishes per point). Twenty-four hours after seeding the cells, test compounds were added (at two selected concentration levels) 
to the medium. Control cultures received only solvent in the place of test chemical. Dimethyl sulphoxide (DMSO) served as the vehicle to solubilize compounds at a final concentration of $0.4 \% \mathrm{v} / \mathrm{v}$ in the culture medium. Preliminary experiments showed that 0.4 $\% \mathrm{v} / \mathrm{v}$ DMSO has no effect on cell survival. The dishes were returned to the incubator for 7 to 8 days and surviving cells were allowed to form colonies. When the colonies became discrete and well defined, the dishes were washed with PBS solution, fixed with methanol, stained with Giemsa and allowed to dry. The number of colonies per dish was counted. The assays were carried out in triplicate.

\section{MTT [3-(4,5-dimethylthiazol-2yl)-2,5- diphenyl tetrazolium bromide)] assay}

MTT assay was performed to assess the cytotoxicity of the plant extracts. (MTT is an yellow dye which is reduced into purple colored formazan crystals by the activity of mitochondrial succinate dehydrogenase enzyme in viable cells). The cells were cultured in 96-well microtitre plates, treated with varying concentrations of different plant extracts for 6-7 days and incubated. At the end of the treatment period, $20 \mu$ l of MTT was added to each well and the plates incubated for $3 \mathrm{~h}$ in a dark chamber. Next, $100 \mu \mathrm{l}$ of DMSO was added to dissolve the formazan crystals and the absorbance read at $540 \mathrm{~nm}$ using ELISA reader [18].

\section{Statistical analysis}

The results are presented as mean \pm standard error (SE). Statistical significance was determined using one-way analysis of variance (ANOVA) and Student's t-test. $P<$ 0.05 was set as the level of significance.

\section{RESULTS}

\section{Effect of plant extracts on cell viability}

The effect of the plant extracts on cell viability is illustrated in Figs $1-4$. The viability of lymphocytes treated with either doddapatre
(C. aromaticus) or neem ( $A$. indica) fell as the concentration of the extracts increased (Fig $1)$. Treatment with $100 \mu \mathrm{g} / \mathrm{ml}$ of either of these two extracts resulted in $50 \%$ inhibition of the cells (Fig 2).

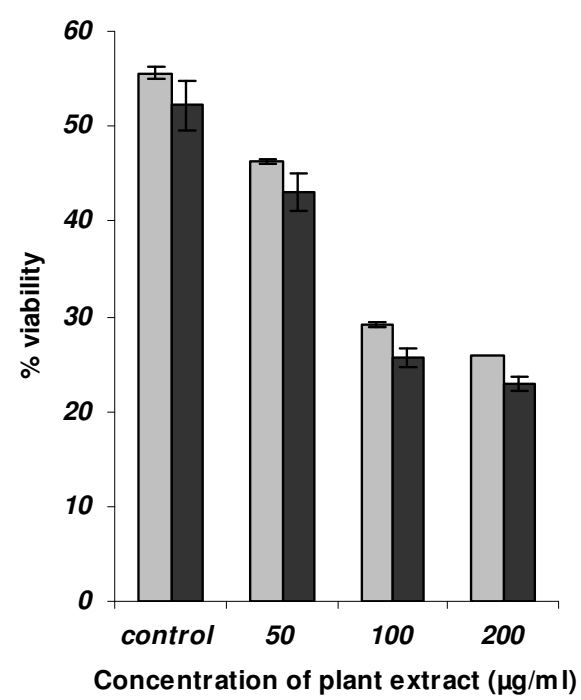

Figure 1: Viability of lymphocytes treated with extracts of $C$. aromaticus (grey bars) and $A$. indica (dark bars)

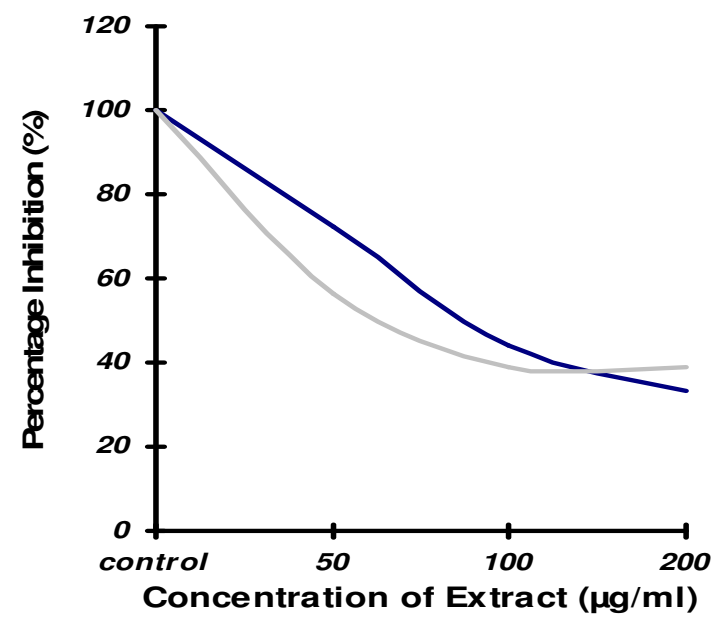

Figure 2: Inhibition of cell survival (MTT assay) by A. indica (grey line) and C. aromaticus (dark line)

Trop J Pharm Res, February 2011;10 (1): 36 


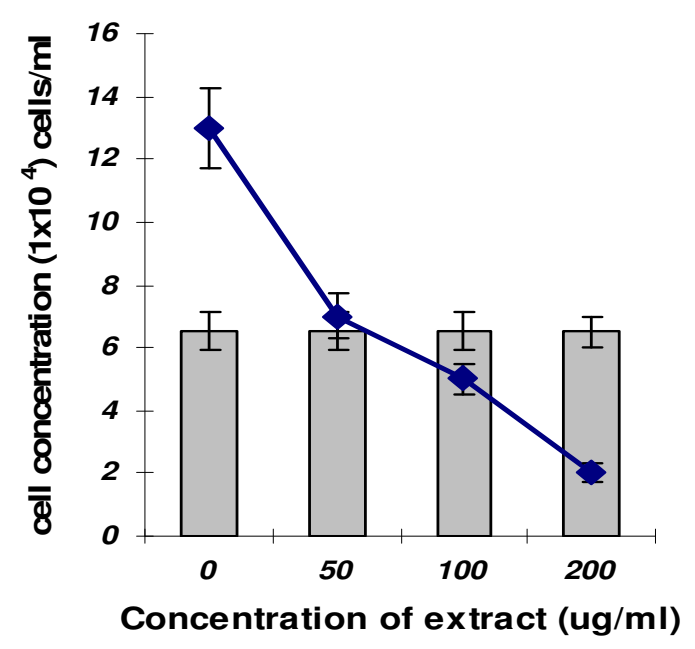

Figure 3: Effect of $P$. niruri on lymphocyte concentration after day 1 (bar) and day 8 (curve)

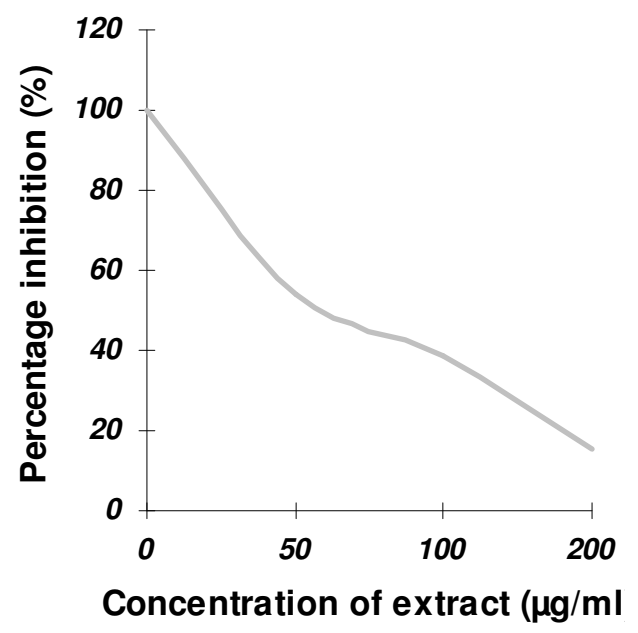

Figure 4: Effect of Phyllanthus niruri on cell survival (determined by MTT assay)

Fig. 3 shows that the cell concentration after 8 days decreased as the extract concentration of $P$. nirurincreased. $\mathrm{IC}_{50}(50 \%$ Inhibitory concentration) value was computed to be $50 \mu \mathrm{g} / \mathrm{ml}$. Treatment with $200 \mu \mathrm{g} / \mathrm{ml}$ of the extract resulted in as much as $85 \%$ reduction in cell viability (Fig. 4). When Balb/c 3T3 mouse fibroblasts were treated with Garcinia indica fruit rind extract, cell concentration also decreased as extract concentration increased (Fig 5). Cell concentration declined to nearly $50 \%$ of the control after 6 days when treated with $80 \mu \mathrm{g} / \mathrm{ml}$ of the extract while the 240 $\mu \mathrm{g} / \mathrm{ml}$ extract produced nearly $80 \%$ inhibition within the same period (Fig 6).

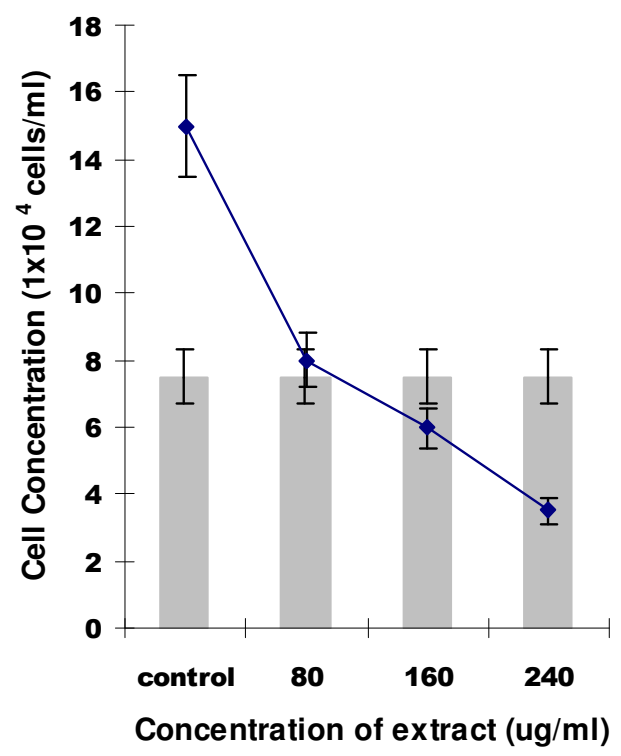

Figure 5: Effect of Kokum (G. indica) on Balb/c Mouse 3T3 Fibroblasts after day 1 (bar) and day 6 (curve)

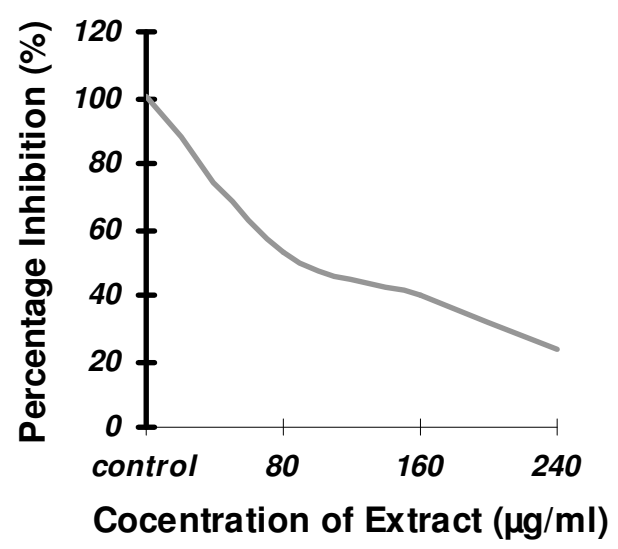

Figure 6: Effect of G. indica on cell survival (determined by MTT assay) 
For green tea (C. sinensis) extract, the results show that cell concentration was higher at extract concentrations of 100 and $200 \mu \mathrm{g} / \mathrm{ml}$ than for control (Fig 7) with the latter extract level producing the highest cell concentration. Figs 8 and 9 also indicate that the viability of the lymphocytes was in the rank order: $200 \mu \mathrm{g} / \mathrm{ml}>100 \mu \mathrm{g} / \mathrm{ml}>$ control. These results were further confirmed by MTT assay, which showed that extract concentrations of 100 and $200 \mu \mathrm{g} / \mathrm{ml}$ increased cell proliferation (Fig 9) compared with control.

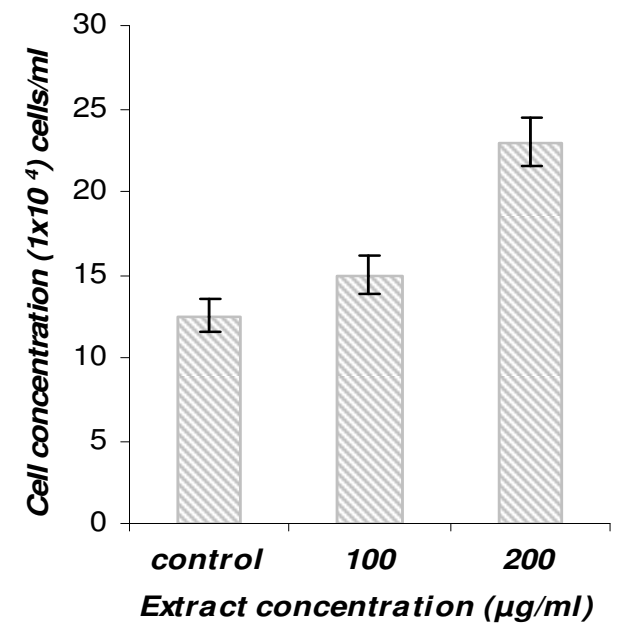

Figure 7: Effect of $C$. sinensis (Green tea) extract on lymphocyte concentration

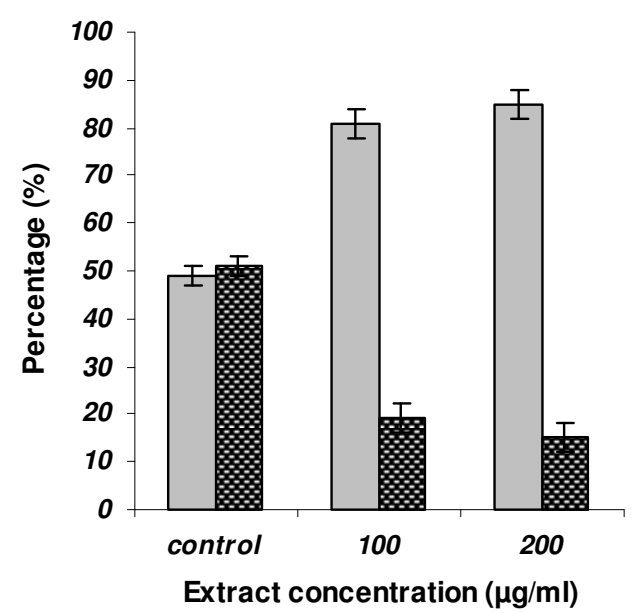

Figure 8: Percent viability of lymphocytes after treatment with $C$. sinensis (green tea).

(Note: Grey bar = viable cells; spotted bar = dead cells)

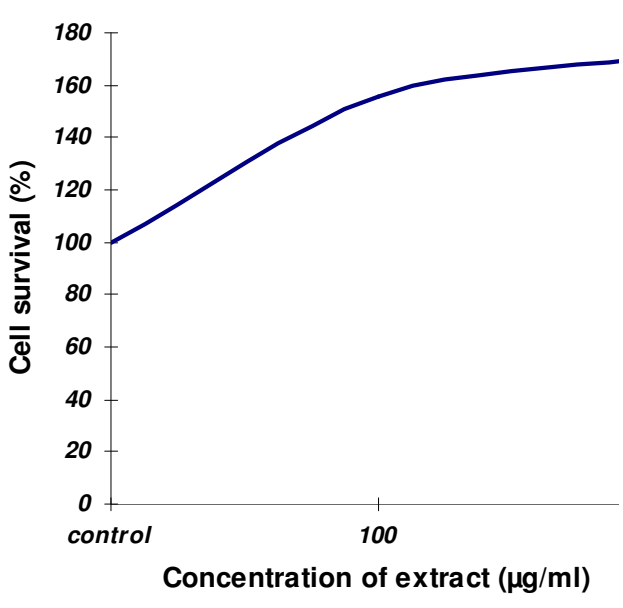

Figure 9: Effect of green tea on lymphocyte survival

\section{DISCUSSION}

A. indica (neem) extract treatment resulted in decreased cell concentration in normal lymphocytes. According to Roy [18], treatment of leukemia and melanoma cells with $0.5-5.0 \mu \mathrm{M}$ concentration of nimbolide resulted in moderate to very strong growth inhibition in human leukaemic lymphoma (U937), human leukemia (HL-60), acute myelogenic leukemia (THP1) and murine melanoma (B16) cell lines. The ethanol extract of neem has been shown to cause death of prostate cancer cells (PC-3) [7]. Nimbolide, a triterpenoid isolate from the flowers of the neem tree, exhibits antiproliferative activity against some cancer cell lines [19] although their side effects on prolonged usage were not reported.

In the present work, we found that neem extract was cytotoxic to normal lymphocytes just like other chemotherapeutic agents at higher concentrations. Our results indicate that they exerted deleterious side effects on normal lymphocytes.

The extract of $\mathrm{C}$. aromaticus also lowered cell concentration. Rao et al [13] reported the antioxidant, anticlastogenic and radioprotective effects of this extract on Chinese 
hamster fibroblast cells (V79) exposed to gamma radiation but there was no data on their effects on normal healthy cells. However, our results show that the extract is cytotoxic at high doses.

$P$. niruri extract was also cytotoxic to normal peripheral human lymphocytes thus indicating that cytotoxicity was probable upon continued and unregulated consumption at high doses. Literature reports indicate that this extract primarily contains lignans (e.g., phyllanthine and hypophyllanthine), alkaloids, and bioflavonoids (e.g., quercetin) [8]. Phyllanthus blocks DNA polymerase, the enzyme required for hepatitis $B$ virus (HBV) to reproduce. It has also been found to inhibit the DNA polymerase of HBV and to bind to $\mathrm{HbsAg}$ in vitro [20]. These earlier workers cautioned against the indiscriminate use of this extract by the populace.

G. indica fruit rind extract reduced the cell concentration and viability of Balb/c mouse fibroblasts. These results are in agreement with those of Hong et al [12] who investigated the effect of an isolate of this plant, garcinol and its oxidative derivatives, cambogin, garcim-1, and garcim-2 on the growth of HT29 and HCT-116 colon cancer cells, as well as on IEC-6 and INT-407 normal immortalized intestinal cells. Garcinol and its derivatives showed potent growth-inhibitory effects on all intestinal cells with $\mathrm{IC}_{50}$ of $3.2-$ $21.4 \mu \mathrm{M}$ after a 3-day treatment. Yamiguchi [21] reported that orally administered garcinol prevented acute ulceration induced with indomethacin in rats and water immersion stress caused by radical formation. The results of Liao et al [22] suggest that garcinol has neuroprotective effects.

Several epidemiologic studies have suggested an association between green tea (C. sinensis) consumption and reduced risk of different kinds of human cancer [23-25]. Hsu et al [26], tested exponentially growing and aged primary human epidermal keratinocytes in response to EGCG or a mixture of the four major green tea polyphenols. EGCG elicited cell differenttiation and proliferation with associated induction of p57/KIP2 within $24 \mathrm{~h}$ in growing keratinocytes. However, the effect of green tea on normal lymphocytes of the human body has not, to the best of our knowledge, been investigated in cell culture systems until now. Our data indicate that it promotes the proliferation of lymphocytes. Of the herbal extracts tested on normal healthy lymphocytes, this plant (green tea) is the only one which was not cytotoxic to lymphocytes. This property should be further explored for the treatment of cell deficiencies of lymphoid origin. Interestingly, this finding supports the reported benefit of green tea consumption in reducing the risk of different types of human cancer.

\section{CONCLUSION}

The findings of our study do not support the routine consumption of the plant extracts evaluated except for $C$. sinensis (green tea). Should they, however, be consumed, it is recommended that the extracts should be prepared exactly according to the recipe and taken in the prescribed doses, bearing in mind that their prolonged use is not advisable.

\section{ACKNOWLEDGEMENT}

The authors are grateful to the management of Jain Group of Institutions for the financial assistance provided to carry out the work.

\section{REFERENCES}

1. Hoyos LS, Au WW, Heo MY, Morris DL, Legator MS. Evaluation of the genotoxic effects of a folk medicine, Petiveria alliacea (anamu). Mutation Research 1992; 280: 29-34.

2. Ishii $R$, Yoshikawa $H$, Minakata NT, Komura $K$, Kada T. Specificity of bio-antimutagens in the plant kingdom. Agricultural and Biological Chemistry Journal 1984; 48: 2587-2591.

3. Ellof JN. Which extractant should be used for the screening and isolation of antimicrobial components from plants? J. Ethnopharmacol. 1998; 60: 1-6.

4. Santos PRV, Oliveira ACX, Tomassini TCB. Controle microbiógico de produtos 
fitoterápicos. Rev. Farm. Bioquím. 1995; 31: 35-38,

5. Ikram $M$, Inamul $H$. Screening of medicinal plants for antimicrobial activities. Fitoterapia 1984; 55: $62-64$.

6. Teixeira RO, Camparoto ML, Mantovani MS, Vicentini VEP. Assessment of two medicinal plants, Psidium guajava L. and Achillea millefolium L., in vitro and in vivo assays. Genetics Molecul Biol 2003; 26(4): 551-555.

7. Kumar S, Suresh PK, Vijayababu MR, Arunkumar A, Arunakaran J. Anticancer effects of ethanolic neem leaf extract on prostrate cancer cell line (PC-3). J. Ethnopharmacol 2006; 105(1-2): 246-250.

8. Bharatiya VB. Selected Medicinal plants of India. Tata Press; Mumbai. 1992. pp. 235-237

9. Nadkarni KM. India Materia Medica. Popular Prakashan; Mumbai. 1993. Vol 1. pp 947-948.

10. Thyagarajan SP, Subramanian $S$, Thirunalasundari $T$, Venkateswaran PS, Blemberg BS. Effect of Phyllanthus amarus on chronic carriers of hepatitis B virus. Lancet 1988; 2: 764-766.

11. Meixa W, Haowei C, Yanjin L. Herbs of the genus Phyllanthus in the treatment of Chronic hepatitis $B$ : observation with three preparation from different geographic sites. J Lab Clin Med 1995; 126: 350-352.

12. Hong J, Kwon S J, Sang S, Ju J, Zhou J, Ho CT, Huang MT, Yang CS. Effects of garcinol and its derivatives on intestinal cell growth: Inhibitory effects and autoxidation-dependent growth-stimulatory effects. Free Radical Biol Med 2007; 42(8): 1211-1221

13. Satish Rao BS, Shanbhoge R, Upadhya D, Jagetia GC. Adiga SK. Kumar P. Guruprasad K, Gayathri P. Antioxidant, anticlastogenic and radioprotective effect of Coleus aromaticus on Chinese hamster fibroblast cells (V79) exposed to gamma radiation. Mutagenesis 2006; 21(4): 237-242.

14. Indian Council of Medical Research. Ethical guidelines for biomedical research on human participants. New Delhi: Indian Council of Medical Research; 2006.

15. Mahudawala DM, Redkar AA, Wagh A, Gladstone $B$, Rao KVK. Malignant transformation of Syrian hamster embryo (SHE) cells in culture by malachite green: An agent of environmental importance. Indian J Exp Biol 1999; 37: 904-918.
16. Panandiker A, Maru GB, Rao KVK. Dose-response effects of malachite green on free radical formation, lipid peroxidation and DNA damage in Syrian hamster embryo cells and their modulation by antioxidants. Carcinogenesis 1994; 15: 2445-2448.

17. Panandiker A, Fernandes $C$, Rao KVK. The cytotoxic properties of malachite green are associated with the increased demethylase, aryl hydrocarbon hydroxylase and lipid peroxidation in primary cultures of Syrian hamster embryo cells. Cancer Lett 1992; 67: 93-101.

18. Roy MK, Kobori M, Takenaka M, Nakahara K, Shinmoto $H$, Isobe $S$, Tsushida $T$. Antiproliferative effect on human cancer cell lines after treatment with nimbolide extracted from an edible part of the neem tree (Azadirachta indica) Phytotherapy Research 2007; 21(3): 243-250

19. Reichert R. Phytotherapeutic alternatives for chronic hepatitis. Quart Rev Natural Med 1997: 103-108.

20. Blumberg BS. Twenty-eighth Scientific report. Institute of Cancer, Research Fox chase, Philadelphia: 1999. pp. 234-237.

21. Yamaguchi $F$, Saito $M$, Ariga $T$ Yoshimura $Y$, Nakazawa H. Free Radical Scavenging Activity and Antiulcer Activity of Garcinol from Garcinia indica Fruit Rind J. Agric. Food Chem. 2000; 48 (6): 2320-2325.

22. Liao CH, Ho CT, Lin JK. Effects of garcinol on free radical generation and NO production in embryonic rat neurons and astrocytes. Biochem Biophys Res Comm. 2005; 329(4): 1306-1314.

23. Katiyar SK, Mukhatar H. Tea in chemoprevention of cancer: epidemiological and experimental studies. Int. J. Oncol. 1996; 8: 221-238.

24. Yang CS, Wang ZY. Tea and cancer: a review. J. Natl. Cancer Inst. 1993; 85: 1038-1049.

25.Chan $\mathrm{H}$, Chan $\mathrm{C}$, Ho JW. Inhibition of glycyrrhizic acid on aflatoxin $B_{1}$-induced cytotoxicity in hepatoma cells. Toxicology 2003; 188(2-3): 211-217.

26. Hsu S, Bollag WB, Lewis J, Huang Q, Singh B, Sharawy $M$, Yamamoto $T$, Schuster GS. Green Tea Polyphenols Induce Differentiation and Proliferation in Epidermal Keratinocytes. JEPT 2003; 306: 29-34. 